\title{
Evaluation of Ethical Issues in the Knowledge Age: An Exploratory Study
}

\author{
Leila Halawi, Bethune Cookman University, halawil@cookman.edu \\ RichardV. McCarthy, Quinnipiac University, richard.mccarthy@quinnipiac.edu
}

\begin{abstract}
Unethical information technology (IT) conduct is estimated to cost billions of dollars in deficits for enterprises. Included in this unethical behavior are issues associated with the knowledge age. Many IT ethics concerns do not have guidelines that are well recognized or broadly accepted. This study will explore the ethical perception of a diverse group of knowledge workers. It will also examine the effects of deterrents, individual factors and external variables to determine if there are noted differences in ethical perceptions that can be explained by these variables.
\end{abstract}

Keywords: Information Technology (IT), Ethics, IT and Ethics, Knowledge Age

\section{INTRODUCTION}

The past two decades have witnessed a fast yet disparate proliferation in computers and information technologies in businesses all over the globe. Society has entered a period driven by computer technologies generally identified as the "Knowledge Age". Managers, researchers, and academicians have become attentive that knowledge and information technologies are critical and significant organizational resources. As societies made the transition from the industrial era to the post-industrial era, the amount and availability of information is significantly greater [27]. Knowledge is a primary resource for organizations [20] and a source of wealth and competitive advantage for society [52]. In this different information-rich environment, most work will involve the production and dissemination of information [35]. Given the importance of IT in the new economy, the knowledge workers who use IT and their manager's benefit from better understanding the relationship between using information technology and performing knowledge work. With this ever-increasing existence of computer technology in our lives, information systems ethics is vital. This knowledge era has produced a recent exemplar for applied ethics, in which the perceptions of privacy, property, accuracy, accessibility, value and the responsibility of the individual and the institution are being redefined. The prevalent diffusion of IT has presented remarkable advantages to businesses and the general public but has also proliferated exploiting these technologies [18].

Even though the investigation of ethical issues associated with computer use developed in the 1980s, it has risen in importance in the subsequent decades. The initial weight was more on the computing profession that translated into questions linked to the development of systems and the conduct of computing professionals. Shortly the spotlight shifted to the Internet and to the users of computer and related communication technologies. Since the amount of business and personal information continues to develop and the access to that information by IT personnel rises, ethics and value reasoning by IT professionals and knowledge workers grow to be imperative [33].

The paper begins by reviewing the relevant literature in the area of information systems ethics. We then present an empirical analysis of the investigation of knowledge workers and IT professionals. The comprehensive model of ethical behavior is then presented. The final section explains the implications of our findings and its impact on the knowledge era.

\section{Ethics in the Knowledge Era}

The rising importance of information technologies to the economic, social, and political life of developed countries moreover started to introduce insightful and extreme questions about the ethical practices of IT and knowledge workers. Regrettably, research that investigates ethical issues associated with the knowledge age is under represented. Overall, no systematic proposal has been instituted in the literature a propos ethical issues applicable to the emerging information technologies and knowledge workers.

The primary purpose of the study is to investigate what new ethical issues are experienced by knowledge workers and IT professionals and how these issues are controlled and addressed. 


\section{Issues in Information Systems}

Volume 14, Issue 1, pp.106-112, 2013

Four primary research questions are proposed for this study:

$\mathrm{Q}(1)$. Have ethics deterrents been effective in decreasing the likelihood of unethical behavior?

$\mathrm{Q}(2)$. Can rival explanations, including the use of code of ethics, education and training explain minor occurrences of unethical behavior?

$\mathrm{Q}(3)$. What are the coping strategies to handle ethical issues in the knowledge age?

$\mathrm{Q}(4)$. Are there overall gender differences in the identification of unethical behavior in ethical dilemmas relating to the knowledge age?

An examination of ethical issues and coping strategies experienced by practitioners is significant for theory building, for practitioners and for policy makers. Public examination of the ethical connotations of novel technologies is an essential component of the processes of social change and adaptation [30]. The findings might facilitate ethics training programs for students and employees as well as offer input to an integrated ethical focal point at the strategic level.

Since IT ethics does not have a generally conventional definition, one of the probable limitations of the study is the participant divergences in understanding and explaining the various ethical issues associated with IT.

\section{Information Technology (IT)}

Any investigation of information technology (IT) should start with an explanation of it. IT can be defined as a set of tools that help work with information and perform tasks related to information processing [22]. IT includes an entire multitude of diverse technologies. When components act in synergy, the resulting data and information to an array of hardware that assists in investigating and comprehending the information will result in knowledge gained by the end-user [31]. IT can be defined as the study or use of processes especially computers, microelectronics and telecommunications for storing, retrieving and sending information of all kinds like words, pictures and numbers [21]. With this value-added information and understanding, end-users can start to generate answers to posed problems and manage their lives, their environment, their jobs and even the entire society and global economies. The purpose of IT is to solve problems, to unlock creativity and to make people more effective than they would if they didn't involve IT in their activities [55]. IT has been cited as one of the key enablers of successful knowledge management (KM) [13, 46, 59, 70].

\section{Knowledge Work}

Knowledge workers contribute to the structural capital of a firm through the knowledge they produce. Stewart [60] said that information and knowledge are both the raw material of knowledge workers' labor and its product. Knowledge work is not clearly defined as a class or a type of work. The U.S. government, for example, does not include "knowledge work" as a separate occupational category with its own standard industrial classification code, but uses categories such as "managers and professionals" and "white-collar" employees [67]. The term "knowledge work" is used to describe a broad type of work in which the primary activities involve the use of mental effort for the purpose of creating information of meaningful value to an organization [16]. Information workers include "all those people who create, manipulate, or disseminate information for living." [31]. There are two kinds of information workers: knowledge workers and data workers. Clearly, using information technology is an important component of knowledge work, where the focus is on knowledge and information. The terms knowledge work and knowledge workers are commonly used in popular and academic literature to describe the kind of work and workers critical to organizational success in post-industrial society [5]. Davenport, Jarvenpaa and Beers [15] explained that knowledge work is about the acquisition, creation, packaging, application or reuse of knowledge. Knowledge work is characterized by variety and exception rather than routine and is performed by professional or technical workers with a high level of skill and expertise [10]. As societies make the transition from the industrial era to the postindustrial era, the amount and availability of information is significantly greater [27]. Knowledge is a primary resource for organizations [20] and a source of wealth and competitive advantage for society [53]. In this different information-rich environment, most work will involve the production and dissemination of information [36]. Given the importance of IT in the new economy, the knowledge workers who use IT and their managers could benefit from better understanding the relationship between using information technology and performing knowledge work.

\section{Ethics Defined}




\section{Issues in Information Systems \\ Volume 14, Issue 1, pp.106-112, 2013}

The study of ethical behavior has been guided by two approaches: 1) a descriptive/empirical/predictive approach from the social sciences and 2) a normative approach routed in philosophy [65]. Compared to normative ethics which assesses circumstances from the "what ought to be" standpoint, descriptive ethics presents a "what is" standpoint. Moral philosophy also considers two types of ethics: teleological focusing primarily on the consequences, results, ends, goals or purposes of agent acts and deontological which centers on the act taken by the agent and the duties, rights, privileges and responsibilities that pertain to that act. There are also hybrid theories mixing elements of teleological and deontological theories and ethical relativism [66].

Individuals generally have a mixed system of ethics. Numerous moral philosophers suggest a mixed deontologicalteleological system of ethics [28].

Ethics is a gray area that deals with actions that are not technically illegal, but are not quite right either [4]. Ethics is defined in different ways and sometimes even conflicting ways depending on one's perceptions, morals and values. Ethics are guidelines to influence human social behavior in a manner intended to protect and fulfill the rights of individuals in a society [38]. Guidelines do not simply mean laws; they also include basic principles of analysis, beliefs and assumptions about the nature of God, the physical word, life, individuals and society and social values [38].

Computer ethics is a vibrant and multifaceted field of study that contemplates the interactions between facts, conceptualizations, guidelines and principles relating to continually varying computer technology [44]. Information ethics is also an important issue [26].

An ethical issue arises whenever one party in pursuit of goals engages in behavior that materially affects the ability of another party to pursue goals [39]. Ethical issues in IT differ from general ethical issues as information in electronic form is more readily available. This raises questions in regard to issues such as intellectual property rights, plagiarism, piracy and privacy when there is less personal contact. One factor behind the interest in IT ethics is a suspicion that IT professionals are unprepared to deal effectively with ethical issues in the workplace [35].

Mason [37] developed a theoretical social framework in dealing with the major information technology ethical issues of the information age. He identified four issues known as PAPA which stand for privacy, accuracy, property and accessibility. The concept of PAPA as the foundation of information ethics has remained popular for over two decades.

Topics within the IT ethics literature may be generally partitioned into four categories: 1) social aspects [29,30,37,32,50]; 2) Group differences [67,49,37,32,43,3,7,65,56,40,23]; 3) technology effects [9]; and 4) foundation, practice, legal aspects and policies [41].

Due to the various ethical problems related to computer technology, several researchers have suggested the implementation of a code of ethics. Several professional organizations such as ACM, DPMA, IEEE, and others have developed a professional code of ethics [69]. Information technology ethics codes have been examined fairly by previous researchers $[54,11,12,68,24,34,25,51]$.

Professionals in the IT field have no single, agreed upon code of conduct [48]. Furthermore, IT professionals are not provided any ethical conflict guidance.

\section{General Deterrence Theory}

The foundation for this study is the criminological theory of general deterrence. Deterrence theory centers on "deterrent" or penalties against performing an unusual deed and the consequence of these penalties on preventing others from performing illicit acts [8]. The theory presumes that impending violators know the efforts to influence rebellious behaviors. People react to regulations and the penalty coupled with operative policing. In information systems, the policing action arises when for example, protection officials utilize deterrents to examine and impose guidelines and circulate information about organizational rules for satisfactory system use. Imposing and implementing harsh sentences for significant safekeeping disturbances is believed to deter impending crooks from unlawful or prohibited behaviors [61]. 


\section{Issues in Information Systems}

Volume 14, Issue 1, pp.106-112, 2013

\section{RESEARCH METHODOLOGY}

Based on prior theory and research a comprehensive model of ethical behavior of knowledge workers is proposed (Figure 1). This integrates individual factors, deterrents, external variables, major ethical philosophies and ethical/unethical judgment. Operationally, the model views the ethical/unethical behavior of knowledge workers to be the effects of these variables. It is generally assumed that a number of individual characteristics, situational factors or external factors influence the likelihood an individual will engage in an unethical activity or situation. A variety of demographic factors are proposed to be related to ethical beliefs and judgment such as age, gender and work experience among others. There is mixed evidence regarding the effect of gender on the choosing of ethical behaviors. Many studies have concluded that females are more ethical $[2,42,57]$. Similarly, Beltramini et al. [6] and Peterson et al. [52] concluded that female students are more concerned about ethical issues than their male counterpart.

The model shows deterrents as a summative unit of behavioral properties [19]. The effect of codes and sanctions on unethical judgments and intentions is consistent with the general deterrence theory of crime [14]. Laws and legal sanctions may lead to total prevention of a specific deviance, or might decrease the occurrence of such acts [64].

Deontological norms represent a set of determined guidelines that signify personal values or rules of behavior [58]. Deontology emphasizes what is right rather than end results. Teleology can be explained as philosophy that deals with the outcomes of the action [28]. In other words, differing from deontology, teleology deems a behavior ethical or unethical based on the advantages resulting from such a behavior. Hunt and Vitell [28] proposed that a person's ethical judgment (the extent to which an individual feels that an action is ethical) is a function of his/her deontological and teleological norms in resolving ethical dilemmas.

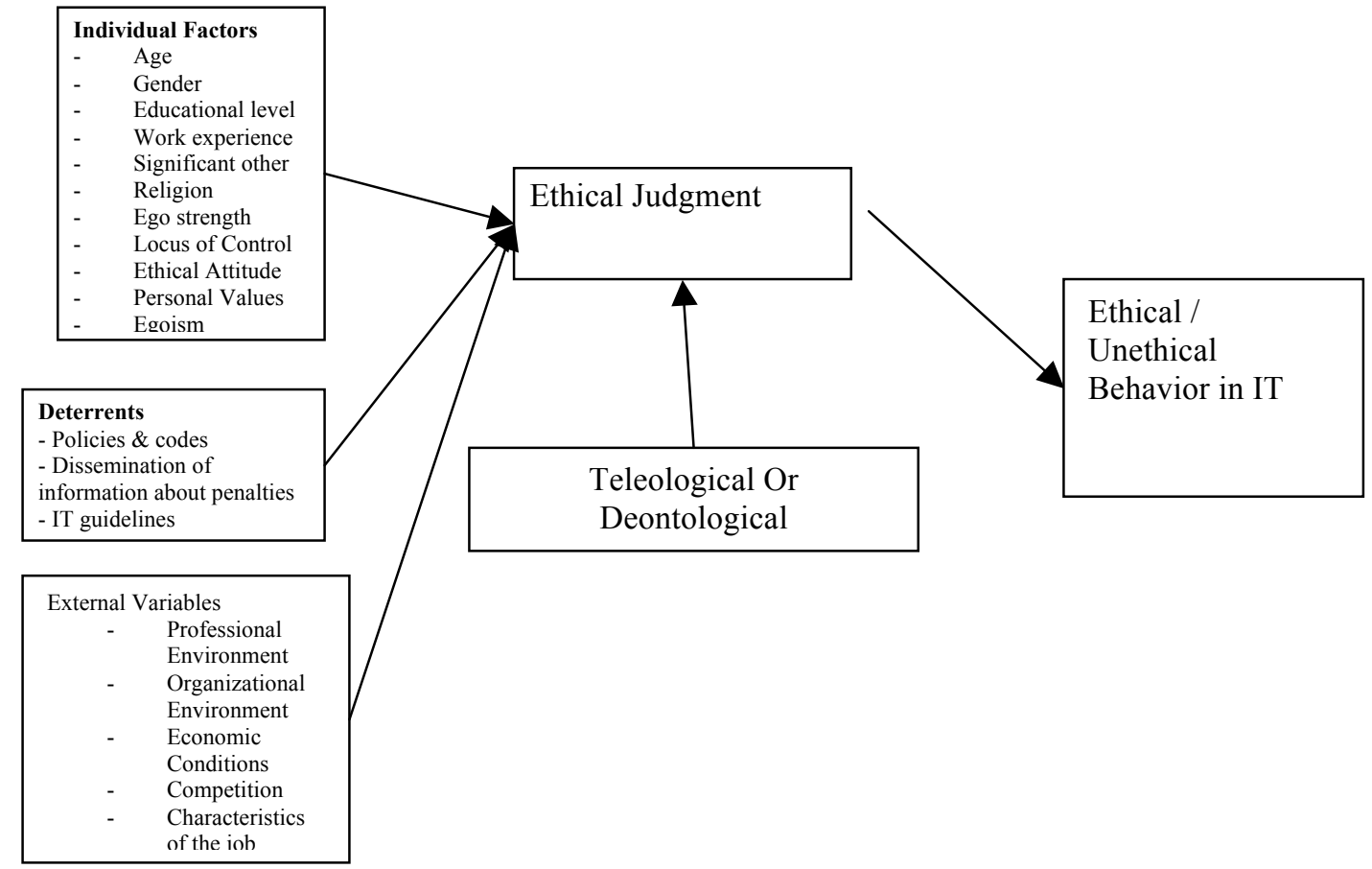




\section{Issues in Information Systems}

Volume 14, Issue 1, pp.106-112, 2013

\section{CONCLUSIONS}

The standing of ethical behavior in the use of IT maintains great importance for both businesses and researchers. Many research studies have been completed to evaluate the effects of several factors on information technology ethical decisions. The financial impact of unethical IT behavior is overwhelming. With the disastrous disclosures inherent in the corporate scandals of this past decade, an assessment of the approach in teaching ethics is needed. While ethical problems were assumed to have existed, the magnitude of the corporate scandals brought to light the financial consequences. We realized that not enough had been done to deter such unethical behavior. Basic public confidence in American business practices, so crucial to health equity markets, seems to be very much in jeopardy. It is thought that unless public confidence had been restored and there existed a general belief that corporations were operating within a climate of greater trust, honesty, and adherence to appropriate standards of governance, the economy was likely to suffer further.

The results of this research will have implications for practitioners and researchers. For IS researchers, there will be two implications: 1) understanding the influences on unethical IT behavior can have major returns if addressed.

2) As businesses and economies become more digital and global, it will become increasingly important to educate knowledge workers and prepare them to behave ethically. This study and extensions of this study will help organizations.

\section{REFERENCES}

[1] Abratt, R., Nel D., \& Higgs, S. N.(1992). An examination of the ethical beliefs of managers using selected scenarios in a cross-cultural environment. Journal of Business Ethics, 11(1), 29-35.

[2] Arlow, P. (1991). Personal characteristics in college students evaluation of business ethics and corporate social responsibility. Journal of Business Ethics, 10, 63-69.

[3] Athey S., (1993). A comparison of experts and high tech students' ethical

beliefs in computer-related situations. Journal of Business Ethics, 12, 359-370.

[4] Anderson, J.: 1997. What Cognitive Science Tells Us About Ethics and the Teaching of Ethics', Journal of Business Ethics 16, 279-291.

[5] Bell, D. (1976). The Coming of Post-Industrial Society: A Venture In Social Forecasting. New York:

BasicPress.

[6] Beltramini, R.P. and Kormetsky, G. (1984). Concerns of college students regarding business ethics. Journal of Business Ethics, 3, 195-200.

[7] Benham, H. C., \& Wagner, J. L. (1995). Ethical attitudes of business

students and MIS personnel. Proceedings of the ACM SIGCPR Conference [online], Nashville TN USA, 44-49.

Available: www.acm.org/pubs/articles/proceedings/cpr/212490/p44-wagner/p44-wagner.pdf.

[8] Blumstein, A., Cohen, J. \& Nagin, D. (1978). Introduction in Deterrence and Incapacitation: Estimating

the Effects of Criminal Sanctions on Crime Rates. National Academy of Sciences, Washington, D.C.

[9] Bommer, M., Gratte, C., Gravander, J., \& Tuttle, M. (1987). A behavioral

model of ethical and unethical decision making. Journal of Business Ethics, 6(4), 265-280.

[10] Broadbent, M. (1998). The Phenomenon of Knowledge Management: What Does It Mean to the Information Profession. Information Outlook, 2(5), 23-31.

[11] Chen, A., Sawyers, R. \& Williams, P. (1997). Reinforcing Ethical decision making through corporate culture. Journal of Business Ethics, 16(8), 855-865.

[12] Cleek, M. \& Leonard, S. (1998). Can corporate codes of ethics influence behavior? Journal of Business Ethics, 17(6), 619-630.

[13] Choi, Y. S. (2000). An Empirical Study of Factors Affecting Successful Implementation of Knowledge Management. Doctoral Dissertation: University of Nebraska.

[14] Cressy, D. R. \& Moore, C. A. (1983). Managerial values and corporate codes of ethics. California Management Review, 25(4), 53-77. 


\section{Issues in Information Systems}

Volume 14, Issue 1, pp.106-112, 2013

[15] Davenport, T. H., Jarvenpaa, S. L., \& Beers, M. C. (1996). Improving Knowledge Work Processes. Sloan Management Review, Summer, 53-65.

[16] Davis, G. B., Collins, R. W., Eierman, M., \& Nance, W. (1991). Conceptual Model For Research On Knowledge Work (Management Information Systems Research Center Working Paper (9110)). Minneapolis: University of Minnesota.

[17] Davis, D. L., \& Vitell, S. J. (1990). Ethical beliefs of MIS professionals:the frequency and opportunity for unethical behavior. Journal of Business Ethics, 9, 63-70.

[18] Dorantes, C. A., Hewitt, B., \& Goles, T. (2006). Ethical decision-making in an IT context: The roles of personal moral philosophies and moral intensity. Proceeding of the Hawaii International

Conference on System Sciences, Big Island, HI, pp. 1-10.

[19] Dubin, R. (1978). Theory Building, Revised Edition, The Free Press, New York.

[20] Drucker, P. F. (1988). Management and The World's Work. Harvard Business Review, Sept-Oct.

[21] Gaillard, W. T. (1999). A Value Assessment Approach Towards Effective Use of Information Technology In Organizations. Retrieved From ProQuest File: Dissertation Item (AAT:1395711) .

[22] Haag, S., \& Keen, P. (1996). Information Technology: Tomorrow's Advantage Today. New York: Mc Graw Hill Companies, Inc.

[23] Halawi, 1 \& Karkoulian,(2006). "Ethical Attitudes of Business Information Systems Students: An Empirical Investigation": Issues in Information Systems: The Changing Role of IS Education, VII(1), 175-178.

[24] Harrington, S. J. (1996). The effects of codes of ethics and personal denial of responsibility on computer abuse judgments and intentions. MIS Quarterly, 20(3), 257-278.

[25] Healy, M. \& Iles, J. (2002). The establishment and enforcement of codes. Journal of Business Ethics, 39(1/2), $117-124$.

[26] Hilton, T. (2000). Information Systems Ethics: A Practitioners Survey, Journal of Business Ethics, 28, 279-284.

[27] Huber, G. P. (1984). The Nature and Design Of Post-Industrial Organizations. Management Science, 3(8), 928951.

[28] Hunt, S. D. \& Vitell,, J. (1986). A general theory of marketing ethics. Journal of Marketing Research, 48, 3042.

[29] Johnson, D. G. (1984). Computer Ethics. Englewood Cliffs, New Jersey, USA, Prentice Hall.

[30] Johnson, D. G. (1985) Equal Access to Computing. Computer Enterprise, and Decision Making about Computers. Business and Professional Ethics Journal, 4(3\&4), 95-103.

[31] Laudon, K. C., Traver, C. G., \& Laudon, J. P. (1996). Information Technology and Society. Cambridge, MA: Course Technology Inc.

[32] Lim, V. K. (2002). The IT way of Loafing on the Job: Cyberloafing, Neutralizing, and Organizational Justice. Journal of Organizational Behavior, 23, 675-694.

[33] Lorents, A. C., Maris, J. M. \& Morgan, J. N. (2006). Ethics of Computer Use: A Survey of student attitudes. Academy of Information and Management Sciences Journal, 9(2), 45-60.

[34] Loch, K.D., \& Conger, S. (1996). Evaluating ethical decision making and computer use. Communications of the ACM, 39(7), 74-83

[35] Maner W. 1996, "Unique Ethical Problems in Information Technology", Science and Engineering Ethics, 2.2, 137-54. Revised version in Maner (1999).

[36] Marien, M. (1984). Some Questions For The Information Society. The Information Society, 3(2), 181-197

[37] Mason, R.O. (1986). Four ethical issues of the information age. MIS Quarterly, 10(1), 4-12.

[38] Marshall, K. (1999). Has Technology Introduced new ethical problems? Journal of Business Ethics, 19(1), 8190.

[39] Mason, R.O., Mason, F. M., \& Culnan, M. J. (1995). Ethics of Information Management. Thousand Oaks, CA:Sage publications.

[40] McCarthy, R., Halawi, L. \& Aronson, J (2005). "Information Technology Ethics: A Research Framework." Issues in Information Systems: The 21st Century Challenges to Information Technology, VI(2), 64-69.

[41] Menzel, D. C. (1998, fall). Ethics attitudes and behaviors in local governments: An empirical analysis. State and Local Government Review, 24, 94-102.

[42] Miesing, P. and Preble, J. (1985). A comparison of five business philosophies. Journal of Business Ethics, 4, 465-476.

[43] Morris, A., Jones, G. \& Rubinsztein, J. (1993). Entry-Level Information Systems Personnel: A Comparative Study of Ethical Attitudes. Proceedings of the 1993 ACM SIGCPR Conference. [online] St Louis Mo USA, 8-17. 


\section{Issues in Information Systems}

Volume 14, Issue 1, pp.106-112, 2013

Available www.acm.org/pubs/articles/proceedings/cpr/158011/p8-morris/p8-morris.pdf

[44] Moore, J. H. (1985). What is Computer Ethics. Metaphilosophy, 16(4), 266-275.

[45] Nunnally, J. C. (1970). Introduction to Psychological Measurement, Mcgraw-Hill, New York.

[46] O'Dell, C., \& Grayson, C. J. (1998). If Only We Knew What We Know: Identification and Transfer of Internal Best Practices. California Management Review, 40(3), 154-174.

[47] Oz, E. (1992). Ethical standards for information systems professionals: A case for a unified code. MIS

Quarterly, 16(4), 423-433.

[48] Oz, E. (1994). Ethics for the information age. Irwin/McGraw-Hill, New York..

[49] Paradice, D. B., \& Dejoie, R. M. (1991). The Ethical Decision-Making Processes of Information Systems

Workers. Journal of Business Ethics, 10, 1-21

[50] Peslak, A. R. (2006). PAPA Revisited: A Current Empirical Study of the Mason Framework. The Journal of Computer Information Systems, 46(3), 117- 123.

[51] Peterson, D. (2002). Computer ethics: The influence of guidelines and universal moral beliefs. Information Technology \& People, 15(4), 346-361.

[52] Peterson, R, Beltramini, R. \& Kozmetsky, G. (1991). Concerns of College students regarding business ethics: A replication. Journal of Business Ethics, 10, 733-738.

[53] Porter, M. E. (1991). Towards A Dynamic Theory of Strategy. Strategic Management Journal, 12, 95-117.

[54] Rezaee, Z., Elmore, R. C. \& Szendi, J. Z. (2001). Ethical behavior in higher education institutions: The role of the code of conduct. Journal of Business Ethics, 30(2), 171-183.

[55] Senn, J. A. (1995). Information Technology in Business: Principles, Practice and Opportunities. New Jersey: Prentice Hall International, Inc.

[56] Siegfried, R. M. (2004). Students attitudes on software piracy and related issues of computer ethics. Ethics and Information Technology. 6, 215-222.

[57] Sims, R., Cheng, H. \& Teegen, H. (1996). Toward a profile of students software piraters. Journal of Business Ethics, 15, 839-849.

[58] Singhapakdi, A. \& Vitell, J. (1991). Research Note: Selected Factors influencing marketers Deontological norms. Journal of the Academy of Marketing Science, 19, 37-42.

[59] Skyrme, D. J. (1999). Knowledge Networking: Creating The Collaborative Enterprise. Massachusetts:

Butterworth \& Heinemann.

[60] Stewart, T. A. (1997). Intellectual Capital: The New Wealth of Organizations. New York: Doubleday.

[61] Straub, D. W., Carlson, P. J. \& Jones, E. H. (1993). Deterring cheating by student programmers: A field experiment in computer security. Journal of Management Systems, 5(1), 33-48.

[62] Straub, D. \& Widom, S. (1984). Deviancy by Bits and Bytes: Computer Abusers and Control Measures, In James H. Finch and E. G. Dougall (Eds), Computer Security: A Global Challenge, Elsevier Science Publishers B. V. (North-Holland) and IFIP, Amsterdam.

[63] Summer, M. \& Werner, K. (1997). Online ethics: A comparison of the attitudes of freshmen, MIS majors, and practitioners. Proceedings of the 1997 conference on computer personnel research.

[64] Title, C. R. (1980). Sanctions and social Deviance: The Question of Deterrence, Praeger Publishers, New York.

[65] Trevino, L. K. (1986). Ethical decision making in organizations: A person situation interactionist model. Academy of Management Review, 11, 601-617.

[66] Tsalikis, J. \& Ortiz-Buonafina, M. (1990). Ethical beliefs differences of males and females. Journal of Business Ethics, 9, 509-517.

[67] U.S. Congress, Office of Technology Assessment, 1988).

http://www.fas.org/ota/technology_assessment_and_congress/

[68] Vitell, S. J. \& Davis, D. L. (1990). Ethical Beliefs of MIS Professionals: The frequency and opportunity for Unethical Behavior. Journal of Business Ethics, 9, 63-70.

[69] Walsham, G. (1996). Ethical theory, codes of ethics, and IS practice. Information Systems Journal, 6, 69-81.

[70] Weil , P., \& Broadbent, M. (1998). Leveraging The New Infrastructure: How Market Leaders Capitalize On Information Technology. Boston, Massachusetts: Harvard Business School Press. 